Volume 9. Nomor 1. Januari 2014
Pandecta
http://journal.unnes.ac.id/nju/index.php/pandecta

\title{
Perspektif Konstitusi Indonesia pada Kerjasama Partai Politik dalam Pemilihan Presiden dan Wakil Presiden
}

\author{
Bayu Dwi Anggono
}

Fakultas Hukum, Universitas Jember, Indonesia

Permalink/DOI http://dx.doi.org/10.15294/pandecta.v9i1.3000

\begin{tabular}{l} 
Info Artikel \\
\hline Sejarah Artikel: \\
Diterima Oktober 2013 \\
Disetujui November 2013 \\
Dipublikasikan Januari 2014 \\
\hline Keywords: \\
Political Parties Cooperation; \\
Election of President and Vice \\
President; the Constitution of \\
Indonesia
\end{tabular}

\begin{abstract}
Abstrak
Dalam rangka menjadikan Presiden dan Wakil Presiden memiliki legitimasi yang lebih kuat dan konsekuensi penegasan sistem pemerintahan presidensial yang dianut, maka pada perubahan ketiga UUD 1945 muncul kesepakatan Presiden dan Wakil Presiden dipilih secara langsung oleh rakyat. Pasangan Calon Presiden dan Wakil Presiden diusulkan oleh partai politik atau gabungan partai politik peserta pemilihan umum. Tujuan penelitian ini adalah untuk menganalisis politik hukum Pemilihan Presiden dan Wakil Presiden secara langsung di Indonesia; menganalisis peran partai politik dalam Pemilihan Presiden dan Wakil Presiden secara langsung; menganalisis praktik kerjasama antar partai politik dalam pemilihan Presiden dan Wakil Presiden; dan mengkaji cara membangun kerjasama partai politik berbasis konstitusi. Metode yang dipergunakan dalam penelitian ini adalah yuridis normatif yaitu pencarian jawaban terhadap permasalahan dan tujuan penelitian bersaranakan kerangka teori hukum normatif. Dari hasil penelitian ini diperoleh jawaban, bahwa praktik kerjasama antar partai politik dalam pemilihan Presiden dan Wakil Presiden selama ini (2004 dan 2009) belum sesuai dengan kehendak awal (original intent) para perumus perubahan UUD 1945 karena menciptakan kerjasama taktis yang bersifat sesaat. UUD 1945 menghendaki kerjasama partai politik dalam pencalonan Presiden dan Wakil Presiden diletakkan dalam dua prinsip besar yaitu: pertama, kerjasama partai politik diharapkan melahirkan kerjasama jangka panjang yang dapat melahirkan penyederhanaan partai politik secara alamiah. Kedua, kerjasama partai politik dalam pemilihan Presiden dan Wakil Presiden haruslah dikaitkan dengan rancang bangun sistem pemerintahan menurut UUD 1945, yaitu sistem pemerintahan presidensial dengan ciri Presiden secara umum tidak tergantung pada ada atau tidak adanya dukungan DPR sebagaimana lazimnya yang berlaku dalam sistem pemerintahan parlementer.
\end{abstract}

\begin{abstract}
In order to make the President and Vice President has a strong legitimacy and consequences of the affirmation of the presidential government system, thus in the third amendment of the 1945 Constitution stated that President and Vice President shall be directly elected by the people. The candidates of the President and Vice President shall be nominated by a political party or coalition of political parties that participating in general election. The objectives of this research are to analyze legal politics of direct elections of president and vice president in Indonesia; to analyze the role of political parties in direct elections of president and vice president; to analyze the practice of cooperation among political parties in President and Vice President election, and reviewing political parties building coalition/cooperation as the basis of constitution. The method used in this study is juridical normative. Juridical normative research is library research, ie research on secondary data based on legal normative frameworks. From this study confirmed that the practice of cooperation among political parties in the presidential election in 2004 and 2009 was not in accordance with the initial will (original intent) of the formulator of the 1945 Constitution because it's created a temporary tactical cooperation. 1945 Constitution required political parties' cooperation in order to nominate the President and Vice President which is placed in two major principles: firstly, political parties cooperation are expected to generate a long-term partnership which can simplify the amount of political parties naturally. Secondly, the cooperation of political parties in the presidential election should be associated with the design of government system according to the 1945 Constitution i.e the presidential system which generally characterized by not depend on the support from the parliament as commonly applicable in the parliamentary system..




\section{Pendahuluan}

Setiap menjelang pagelaran pemilihan Presiden dan Wakil Presiden suasana kehidupan ketatanegaraan Indonesia selalu ramaikan oleh rencana koalisi antar partai politik dalam mengusung calon Presiden dan calon Wakil Presiden. Menurut Kamus Besar Bahasa Indonesia (KBBI) Daring Edisi III, April 2014, yang dimaksud koalisi adalah kerja sama antara beberapa partai untuk memperoleh kelebihan suara di parlemen. Koalisi sebagai kata kerja (berkoalisi) artinya adalah bekerja sama antara beberapa partai. Dari dua pengertian tersebut dapat dikatakan, titik tekan koalisi adalah kerjasama.

Sejak pemilihan Presiden dan Wakil Presiden secara langsung dilaksanakan pertama kali pada Tahun 2004, yang dilanjutkan pada tahun 2009, dan 2014 substansi pembahasan mengenai koalisi (kerjasama) antar politik dalam mengusung calon Presiden dan calon Wakil Presiden terlihat sangat mendominasi dibandingkan pembahasan mengenai visi dan misi calon Presiden dan calon Wakil Presiden itu sendiri. Berdasarkan hasil survei oleh Lingkaran Survei Indonesia (LSI) Network yang dilaksanakan tanggal 15 hingga 18 April 2014 terkait program para kandidat calon Presiden didapati hasil mayoritas masyarakat tidak mengetahui program apa yang akan diusung para calon Presiden dan juga visi misi para pemimpin ke depannya nanti (http://www.merdeka.com, 5 Juni 2014).

Sebanyak 63,80 persen mayoritas publik tidak tahu apa yang akan diperjuangkan para calon Presiden. Hanya 18.90 persen yang mengetahuinya. Sementara itu 17.30 persen tidak menjawab. Hal ini disebabkan para calon Presiden terlalu asyik dengan membentuk koalisi sehingga melupakan sosialisasi program, visi dan misi. Partai politikpartai politik terlalu sibuk melakukan manuver-manuver politik untuk mengurusi koalisi. Tetapi sangat miskin gagasan dan visi misi caIon Presiden jika nantinya terpilih. Akibatnya berdampak pada rendahnya pengetahuan masyarakat tentang sosok pemimpin yang akan dipilihnya, padahal masyarakat ingin mengetahui, program calon pemimpin diantaranya yaitu aspek ekonomi, aspek politik, dan aspek budaya (http://www.merdeka.com, 5 Juni 2014).

Kerjasama antar partai politik dalam berbagai momentum politik selama ini masih dianggap lebih kental aroma politik transaksional dibanding kerjasama substantif yang memiliki perspektif jangka panjang. Politik transaksional antar partai politik dalam melakukan kerjasama (yang terkadang diselingi antara individu yang berniat menjadi pajabat publik dengan partai politik) untuk pengisian posisi pejabat publik tertentu dalam kenyataannya terjadi berlapis-lapis(bertingkattingkat). Dikaitkan dengan Pemilihan Umum Anggota Legislatif dan Pemilihan Umum Presiden dan Wakil Presiden), politik transaksional bisa terjadi 4 sampai 5 kali, yakni: (i) pada saat mengajukan calon-calon anggota legislatif; (ii) pada saat mengajukan calon Presiden dan calon Wakil Presiden karena ketentuan Presidential Treshold; (iii) setelah diketahuinya hasil Putaran Pertama Pemilihan Umum Presiden (jika dibutuhkan Putaran Kedua); (iv) pada saat pembentukan kabinet; (v) pada saat membentuk semacam koalisi di Dewan Perwakilan Rakyat yang kemudian menjadi sejenis prototype untuk koalisi di Dewan Perwakilan Rakyat Daerah (Provinsi dan Kabupaten/Kota) (Keterangan Pemohon (Effendi Gazali) dalam Putusan MK Nomor 14/PUU-XI/2013 tentang Pengujian Undang-Undang Nomor 42 Tahun 2008 tentang Pemilihan Umum Presiden dan Wakil Presiden).

Selama ini kerjasama antar partai politik dianggap belum mampu menjawab tantangan yang dianggap menentukan keberhasilan kinerja sistem pemerintahan presidensial di Indonesia pasca perubahan UUD 1945 yang mencerminkan pengakuan atas gagasan kedaulatan rakyat dan sekaligus kedaulatan hukum yaitu terkait dengan penataan sistem kepartaian (penyederhaan jumlah partai). Dengan sistem Presidensil yang dibarengi sistem multi partai di Indonesia dewasa ini kebuntuan politik (political gridlock) setiap saat mungkin dapat terjadi dalam penyelenggaraan kenegaraan. Untuk mencegah hal tersebut Presiden dan Wakil Presiden terpilih seringkali mau tidak mau harus menjalin kerjasama "yang dipaksakan" dengan berbagai 
partai politik yang mempunyai agenda politik yang berbeda yang ada di DPR agar dapat menjalankan pemerintahan.

Akibat kerjasama antar partai politik terkesan dipaksanakan maka kerjasama yang dibangun bukan berdasarkan ideologi atau platform politik, tetapi lebih karena hasrat untuk menguasai jabatan-jabatan pemerintahan. Kerjasama antar partai politik dalam pemilihan Presiden dan Wakil Presiden juga sering dilakukan tanpa waktu yang cukup untuk membangun kerjasama dan merumuskan platform politik, karena partai politikpartai politik menjajaki kerjasama dalam waktu singkat mendekati akhir pendaftaran calon Presiden dan calon Wakil Presiden. Padahal waktu yang cukup diperlukan agar dalam membangun kerjasama, mereka bisa merumuskan platform politik yang menjadi panduan ketika berkuasa, dan membagi-bagi kursi kekuasaan secara lebih sehat.

Dalam setiap pagelaran pemilihan Presiden dan Wakil Presiden setidaknya terdapat dua kutub pemikiran mengenai bentuk kerjasama partai politik, pertama, yang menyakini bahwa partai politik pengusung calon Presiden dan calon Wakil Presiden harus mengajak sebanyak mungkin mitra kerjasama dengan tujuan tidak hanya memenuhi persyaratan pengajuan calon Presiden dan wakil Presiden yaitu sejumlah perolehan kursi DPR atau suara sah nasional Pemilu anggota DPR (Presidensial Threshold) sebagaimana diatur Undang-Undang Pemilihan presiden, melainkan juga untuk menjamin efektivitas dan stabilitas pemerintahan. Efektivitas pemerintahan tidak mungkin tercapai apabila DPR tidak "ditaklukkan" oleh calon Presiden dan calon Wakil Presiden terpilih melalui pembagian kursi menteri kepada partai politik-partai politik mitra kerjasama.

Dalam titik ekstrem kutub ini menyakini bahwa kerjasama antar partai politik tidak mungkin terwujud tanpa adanya kesepakatan mengenai pembagian menteri-menteri antar partai politik sebelum pelaksanaan pemilihan Presiden dan Wakil Presiden. Kutub ini menihilkan kerjasama sedikit partai politik dan mengangggap bahwa kerjasama semacam itu hanya akan menguntungkan partai politik tertentu dan merupakan wujud ketamakan partai politik tertentu dalam memegang kekuasaan pemerintahan, mengingat mendasarkan pada hasil pemilu legislatif tidak ada partai politik yang dominan di DPR.

Kedua, kutub yang berpandangan bahwa kerjasama antar partai politik merupakan keniscayaan dalam menjalankan kekuasaan pemerintahan, namun melandaskan pada argumentasi kerjasama besar yang didasarkan pada bagi-bagi menteri dan jabatan lainnya tidak menjamin efektivitas pemerintahan maka kerjasama partai politik harus dilakukan dengan pola yang berbeda. Pola yang dimaksud adalah kerjasama harus dimulai dengan mendasarkan pada kesamaan ide dan progam partai politik dalam menyelesaikan persoalan bangsa. Mengenai pembagian jatah menteri-menteri dalam kabinet diserahkan kepada kebijaksanaan calon Presiden dan calon Wakil Presiden terpilih dengan tetap mendengarkan saran dan masukan gabungan partai politik pengusung. Kerjasama semacam ini tetap mengharapkan jumlah partai politik yang bergabung sebanyak mungkin, namun tidak merasa takut jika pada akhirnya dikarenakan tidak ada kesamaan ide dan progam, partai politik yang bergabung sedikit dan tidak mencapai mayoritas di DPR, dengan kata lain calon Presiden dan calon Wakil Presiden terpilih sudah disiapkan menghadapi berbagai "serangan" oleh partai politik non kerjasama yang ada di DPR.

Dari jajak pendapat surat kabar Kompas yang dilaksanakan pada akhir April 2014 menunjukkan secara umum publik kurang bisa menerima koalisi yang didasarkan pada kepentingan kelompok atau partai politik. Dua dari tiga responden sepakat, koalisi adalah kerja sama politik untuk kepentingan bangsa. Koalisi juga dipahami mayoritas responden sebagai kerja sama antar Partai politik yang dibangun berdasarkan persamaan ideologi dan bertujuan menjaga stabilitas pemerintahan (http://nasional.kompas.com, 5 Juni 2014).

Mayoritas responden menyatakan tidak setuju dengan koalisi yang berorientasi pada bagi-bagi jabatan atau kekuasaan. Alihalih menyejahterakan rakyat, koalisi seperti ini, menurut sebagian responden, sarat dengan potensi konflik internal sehingga program 
pemerintah tersendat-sendat akibat terhambat kepentingan partai politik (http://nasional. kompas.com, 5 Juni 2014). Untuk keluar dari kondisi kerjasama antar partai politik yang terkesan transaksional sekaligus untuk menciptakan lingkungan yang lebih dapat menjamin sistem pemerintahan presidensial dapat berfungsi dengan efektif maka diperlukan penataan kerjasama antar partai politik. Oleh karena itu perlu diberikan analisis terkait beberapa kutub pemikiran mengenai bentuk kerjasama antar partai politik dari perspektif kehendak awal para perumus perubahan UUD 1945 sebagai hukum dasar Indonesia. Tulisan ini akan membahas mengenai kerjasama antar partai politik dalam pemilihan Presiden dan Wakil Presiden dari sudut pandang konstitusionalisme Indonesia.

\section{Metode Penelitian}

Tulisan dalam artikel ini dapat dikategorikan dalam jenis penelitian yuridis normatif. Pendekatan yuridis normatif yang dimaksud bercirikan pada pencarian jawaban terhadap permasalahan dan tujuan penelitian bersaranakan kerangka teori hukum normatif, dalam arti pisau analisis yang dipergunakan untuk menelaah data adalah teori-teori yang lazim dikenal dalam teori hukum doktrinal seperti kaidah-kaidah hukum, asas-asas hukum, pengertian-pengertian pokok hukum dan sebagainya (Hidayat, 2006:52).

\section{Hasil dan Pembahasan}

\section{a. Politik Hukum Pemilihan Presiden dan Wakil Presiden secara Langsung di Indonesia}

Pemilihan Presiden dan Wakil Presiden secara langsung merupakan buah dari dilakukannya perubahan UUD 1945 pada tahun 1999-2002. Perubahan UUD 1945 dilakukan sebagai bentuk memenuhi tuntutan reformasi 1998 yang didesakkan oleh berbagai komponen bangsa, termasuk mahasiswa dan pemuda. Terdapat enam tuntutan reformasi pada waktu itu yaitu: (1) Amandemen UUD 1945; (2) Penghapusan doktrin dwifungsi Angkatan Bersenjata Republik Indonesia (ABRI); (3) Penegakan supremasi hukum, penghormatan hak asasi manusia (HAM), serta pemberantasan korupsi, kolusi, dan nepotisme (KKN); (4) Desentralisasi dan hubungan yang adil antara pusat dan daerah (otonomi daerah); (5) Mewujudkan kebebasan pers; (6) Mewujudkan kehidupan demokrasi (Sekretariat Jenderal MPR: 2012: 6.)

Dalam melaksanakan perubahan pertama sampai dengan perubahan keempat UUD 1945 (1999-2002), MPR memiliki lima kesepakatan dasar. Lima kesepakatan itu adalah: (1) tidak mengubah Pembukaan UUD 1945 (2) tetap mempertahankan Negara Kesatuan Republik Indonesia (3) mempertegas sistem pemerintahan presidensial; (4) Penjelesan UUD 1945 yang memuat hal-hal normatif akan dimasukkan ke dalam pasal-pasal (batang tubuh) (5) melakukan perubahan dengan cara addendum (Sekretariat Jenderal MPR: 2012: 18).

Kesepakatan dasar tersebut menjadi pedoman dan petunjuk pembahasan substansi selama berlangsungnya rapat-rapat perubahan pasal-pasal UUD 1945. Kesepakatan dasar untuk mempertegas sistem presidensial bertujuan untuk memperkukuh sistem pemerintahan stabil demokratis yang dianut oleh negara Republik Indonesia yang pada tahun1945 telah dipilih oleh pendiri negara ini (Sekretariat Jenderal MPR: 2012: 19).

Upaya mempertegas sistem presidensial merupakan salah satu proses pembahasan yang paling panjang, mulai dari masa perubahan pertama hingga diputuskan dalam perubahan keempat. Pada perubahan pertama pada tahun 1999 dilakukan dengan menghilangkan kecenderungan executive heavy dalam UUD 1945, di antaranya membatasi kekuasaan Presiden untuk membentuk undang-undang, masa jabatan Presiden dan Wakil Presiden, sumpah dan janji Presiden dan Wakil Presiden, kekuasaan Presiden dalam mengangkat duta dan konsul, kekuasaan Presiden memberi grasi, rehabilitasi, amnesti, dan abolisi, kekuasaan Presiden memberi gelar, tanda jasa, dan lain-lain tanda kehormatan (Perubahan Pasal 5 Ayat (1), Pasal 7, Pasal 9, Pasal 13, Pasal 14, dan Pasal 15 UUD 1945) (Sekretariat Jenderal dan Kepaniteraan Mahkamah Konstitusi: 2010: 5) 
Pada perubahan kedua, tidak ada ketentuan yang berkaitan dengan lembaga kepresidenan yang dapat diputuskan sebagai perubahan UUD 1945. Pada Perubahan Ketiga UUD 1945 Rumusan perubahan baru dapat dihasilkan lagi, yaitu terkait dengan persyaratan Presiden dan Wakil Presiden, pemilihan Presiden dan Wakil Presiden secara langsung oleh rakyat, pemberhentian Presiden dan/ atau Wakil Presiden dan mekanismenya, larangan Presiden untuk membubarkan dan/ atau membekukan DPR, Presiden mangkat, berhenti, diberhentikan atau tidak dapat melakukan kewajibannya serta pemilihan Wakil Presiden, dan kekuasaan Presiden dalam membuat perjanjian internasional (Perubahan Pasal 6, Pasal 6A, Pasal 7A, Pasal 7B, Pasal 7C, Pasal 8 Ayat (1) dan (2), Pasal 11 Ayat (2) dan (3) UUD 1945) (Sekretariat Jenderal dan Kepaniteraan Mahkamah Konstitusi: 2010: 6). Selanjutnya pada Perubahan Keempat diputuskan, yaitu terkait dengan putaran kedua pemilihan Presiden dan Wakil Presiden, pelaksana tugas kepresidenan apabila Presiden dan Wakil Presiden berhalangan secara bersamaan, kekuasaan Presiden menyatakan perang, membuat perdamaian dan perjanjian dengan negara lain, dan pembentukan dewan pertimbangan Presiden (Perubahan Pasal 6A Ayat (4), Pasal 8 Ayat (3), Pasal Pasal 11 Ayat (1), dan Pasal 16 UUD 1945) (Sekretariat Jenderal dan Kepaniteraan Mahkamah Konstitusi: 2010: 5).

Kesepakatan Presiden dan Wakil Presiden dipilih secara langsung oleh rakyat disahkan sebagai bagian dari Perubahan Ketiga UUD 1945 tepatnya pada Rapat Paripurna Masa Sidang Tahunan MPR RI Tahun 2001 Ke-7. Pasal yang mengatur mengenai Pemilihan Presiden disepakati dalam Pasal 6A ayat (1) yaitu Presiden dan Wakil Presiden dipilih dalam satu pasangan secara langsung oleh rakyat. Kesepakatan pemilihan Presiden dan Wakil Presiden langsung diambil dengan pertimbangan sebagai konsekuensi dari ketentuan kedaulatan berada di tangan rakyat, sehingga semua lembaga negara harus dibentuk oleh rakyat. Pembentukan oleh rakyat terhadap lembaga-lembaga negara di antaranya ada yang langsung, dan ada yang tidak langsung, yang langsung dibentuk oleh rakyat adalah lembaga legislatif dan Presiden. Sementara lembaga yang lain, pemilihannya tidak secara langsung oleh rakyat (Sekretariat Jenderal dan Kepaniteraan Mahkamah Konstitusi: 2010: 221).

Pertimbangan lainnya dihubungkan dengan demokratisasi dan legitimasi sistem pemerintah presidensial yang dianut, sehingga tepat jika Presiden dan Wakil Presiden merupakan satu paket yang dipilih langsung oleh rakyat (Sekretariat Jenderal dan Kepaniteraan Mahkamah Konstitusi: 2010: 441). Pemilhan Presiden dan Wakil Presiden secara langsung oleh rakyat, menjadikan Presiden dan Wakil Presiden mempunyai legitimasi yang lebih kuat. Jadi adanya ketentuan tersebut berarti memperkuat sistem pemerintahan presidensial yang dianut oleh Indonesia (Fatwa, 2009: 63).

Pilihan untuk memilih model pemilihan Presiden dan Wakil Presiden secara langsung ini juga berdasarkan pada pengalaman pemilihan Presiden dan Wakil Presiden pada Era Orde Baru dan dalam Sidang Umum MPR tahun 1999 (http://www.saldiisra. web.id/index.php?option $=$ com_content $\&$ view $=$ article\&id=23: pemilihanpresidenlangsung\&cati $\mathrm{d}=1$ :artikelkompas\&ltemid $=2$, diakses 1 Juni 2014). Beberapa raison d'etre yang sangat mendasar untuk melakukan pemilihan Presiden dan Wakil Presiden langsung: pertama, Presiden dan Wakil Presiden yang terpilih melalui pemilihan langsung akan mendapat mandat dan dukungan yang lebih riil rakyat sebagai wujud kontrak sosial antara pemilih dengan tokoh yang dipilih. Kedua, pemilihan Presiden dan Wakil Presiden langsung secara otomatis akan menghindari intrik-intrik politik dalam proses pemilihan dengan sistem perwakilan. Intrik politik akan dengan mudah terjadi dalam sistem multipartai. Ketiga, Pemilihan Presiden dan Wakil Presiden langsung akan memberikan kesempatan yang luas kepada rakyat untuk menentukan pilihan secara langsung tanpa mewakilkan kepada orang lain. Kecenderungan dalam sistem perwakilan adalah terjadinya penyimpangan antara aspirasi rakyat dengan wakilnya. Keempat, pemilihan langsung dapat menciptakan perimbangan antara berbagai kekuatan dalam penyelenggaraan negara terutama 
dalam menciptakan mekanisme checks and balances antara Presiden dengan lembaga perwakilan karena sama-sama dipilih oleh rakyat (Isra, 2001).

Pemilihan secara langsung merupakan salah satu ciri sistem pemerintahan presidensial sebagaimana dikemukan oleh Satori mengenai tiga ciri utama sistem pemerintahan presidensial yaitu: (a) kepala pemerintahan (presiden) dipilih secara langsung oleh rakyat untuk jabatan tertentu; (b) dalam masa jabatannya presiden tidak dapat dijatuhkan oleh parlemen, dan (c) presiden memimpin secara langsung pemerintahan yang dibentuknya (Ismanto, et al, 2004: 31).

Verney menambahkan sejumlah ciri dalam sistem pemerintahan presidensial, yaitu: (a) kekuasaan eksekutif bersifat tidak terbagi (sole executive) dimana jabatan kepala negara (head of state) sekaligus adalah kepala pemerintahan (head of government); (b) presiden tidak dapat membubarkan parlemen; (c) eksekutif bertanggung jawab kepada konstitusi dan secara langsung kepada para pemilih (rakyat) (Ismanto, et al, 2004: 32).

Sistem Pemilihan Presiden dan Wakil Presiden yang sebelumnya dipilih oleh MPR dengan suara terbanyak diubah menjadi dipilih secara langsung oleh rakyat. Sistem ini diyakini membawa sejumlah dampak positif dalam mendorong perubahan politik dan demokrasi yaitu, pertama, pemilihan secara langsung oleh rakyat memberikan basis legitimasi yang kuat bagi Presiden. Kedua, didukung oleh legitimasi yang kuat dari rakyat, Presiden tidak perlu terikat oleh fraksi-fraksi politik di lembaga legislatif. Konsekuensi dari sistem pemilihan Presiden yang baru itu, Presiden tidak lagi mudah dijatuhkan oleh lembaga legislatif hanya karena pertimbangan atau alasan politis. Ketiga, sistem pemilihan secara langsung oleh rakyat memberi kesempatan kepada setiap warga negara (pemilih) untuk memberikan penilaian tentang caloncalon Presiden dan karenanya mendorong dan sekaligus menuntut kematangan politik rakyat dalam berpartisipasi menentukan pergantian pemerintahan. Keempat, sistem baru pemilihan secara langsung akan mengurangi distorsi suara rakyat sehingga terhindar dari praktek "membeli kucing dalam karung". Ke- lima, pemilihan secara langsung oleh rakyat relatif melemahkan insentif praktek-praktek penggunaan kekuatan politik uang dibanding bila sistem itu diserahkan pada anggota MPR yang jumlahnya terbatas (Ismanto, et al, 2004: 33).

Pemilihan Presiden dan Wakil Presiden secara langsung ini pada dasarnya juga sudah sesuai dengan dua cara utama pengisian jabatan Presiden yang umum berlaku yaitu: Pertama, pemilihan langsung (popular vote). Rakyat secara langsung memilih calon-calon Presiden yang diajukan atau memajukan diri dalam pemilihan (Asshiddiqie, dkk, 2006: 36)

Kedua, pemilihan tidak langsung (indirect popular vote). Pemilihan tidak langsung dapat dibedakan antara: (i) Presiden dipilih oleh badan perwakilan rakyat seperti parlemen atau dewan perwakilan rakyat; (ii) Presiden dipilih oleh badan atau lembaga pemilih (electoral college) yang sengaja "dibentuk" melalui pemilihan langsung oleh rakyat untuk setiap kali pemilihan Presiden; (iii) Presiden dipilih oleh badan perwakilan rakyat pusat bersama-sama dengan badan perwakilan rakyat negara bagian; (iv) Presiden dipilih oleh badan perwakilan rakyat pusat dan oleh anggota-anggota yang khusus dipilih badan perwakilan rakyat negara bagian (Asshiddiqie, dkk: 2006: 37).

\section{b. Peran Partai Politik dalam Pemilihan Presiden dan Wakil Presiden Secara Langsung}

Di luar kesepakatan mengenai pemilihan Presiden dan Wakil Presiden dilaksanakan secara langsung, Rapat Paripurna Sidang Tahunan MPR Tahun 2001 Ke-7 (perubahan ketiga UUD 1945) juga menyepakati mengenai rumusan tentang tata cara pemilihan Presiden dan Wakil Presiden dalam satu pasangan yang dipilih langsung oleh rakyat. Pasal 6A ayat (2) UUD 1945 setelah perubahan mengatur Pasangan calon Presiden dan Wakil Presiden diusulkan oleh partai politik atau gabungan partai politik peserta pemilihan umum sebelum pelaksanaan pemilihan umum. Pasal 6A ayat (2) mengandung dua substansi pokok yaitu pasangan calon Presiden dan calon Wakil Presiden hanya dapat 
diusulkan oleh partai politik atau gabungan partai politik peserta pemilu dan UUD 1945 memberi peluang kerjasama partai politik dalam mengusulkan pasangan calon Presiden dan calon Wakil Presiden.

Substansi yang pertama menunjukkan bahwa UUD 1945 tidak memberi peluang diajukannya calon Presiden dan calon Wakil Presiden dari jalur perseorangan atau calon-calon dari luar partai politik. Dalam risalah pembahasan perubahan UUD 1945 dijelaskan alasan tidak diakomodirnya calon perseorangan dalam pemilihan Presiden dan Wakil Presiden yaitu Pertama, partai politik merupakan salah satu syarat-syarat dari sistem demokrasi, dalam sistem seperti ini peran partai politik merupakan faktor yang harus ditumbuh kembangkan dalam rangka membangun proses demokrasi yang sedang berlangsung salah satunya melaksanakan aspirasi rakyat termasuk memilih wakil rakyat di parlemen maupun Presiden dan Wakil Presiden (Sekretariat Jenderal dan Kepaniteraan Mahkamah Konstitusi: 2010: 410).

Kedua, sangat diperlukan para pemimpin yang berkecimpung dalam politik mendidik bangsa dan rakyatnya ke arah lebih baik sehingga peran partai politik menjadi sangat penting. Sehingga diharapkan dalam sistem demokrasi Indonesia partai politiklah yang menjembatani, yang melakukan pendidikan bangsa dan juga menampung aspirasi serta merasionalkannya. Keterwakilan penduduk telah diwadahi oleh partai politik, karena partai politik itulah yang bisa disebut semacam jembatan penghubung rakyat dalam penyelenggaran negara. Apabila bangsa Indonesia sepakat bahwa sistem politiknya berbasis partai politik maka partai politik diberdayakan. Jadi kalau masalahnya kemudian partai politik tidak beres, maka partai politiknya harus disehatkan. Jadi tidak merombak mengenai pengertian demokrasi tersebut (Sekretariat Jenderal dan Kepaniteraan Mahkamah Konstitusi: 2010: 321).

Ketiga, pertimbangan lainnya calon presiden dan calon wakil presiden yang tidak diajukan oleh dari partai politik akan banyak menimbulkan persoalan, dianalogikan seorang yang memiliki banyak modal dan membangun kepopuleran melalui iklan di media massa yang seandainya kemudian terpilih menjadi Presiden akan berhadapan dengan parlemen atau DPR/MPR yang basisnya adalah partai politik (Sekretariat Jenderal dan Kepaniteraan Mahkamah Konstitusi: 2010: 271).

Pilihan para perumus perubahan UUD 1945 untuk terus menumbuhkembangkan peran partai politik dengan jalan memberikan peran yang sangat besar dalam pengajuan usul pasangan calon Presiden dan Wakil Presiden setidaknya memiliki relevansi apabila dikaitkan dengan pendapat Jimly Asshiddiqie yang menyatakan partai politik memainkan peran penghubung yang sangat strategis antara proses-proses pemerintahan dengan warga negara (www.jimly.com, 2 Juni 2014:1).

Bahkan dikatakan oleh Schattscheider "Political parties created democracy" (Partai politiklah yang sebetulnya menentukan demokrasi) (www.jimly.com, 2 Juni 2014). Karena itu, partai politik merupakan pilar yang sangat penting untuk diperkuat derajat pelembagaannya (the degree of institutionalization) dalam setiap sistem politik yang demokratis. Bahkan, oleh Schattscheider dikatakan pula, "Modern democracy is unthinkable save in terms of the parties" (www.jimly.com, 2 Juni 2014)

Pandangan untuk memperkuat peran partai politik dalam negara demokratis Indonesia sebagaimana menjadi kesepakatan para pengubah UUD 1945 sejalan dengan pendapat Miriam Budiardjo mengenai fungsi partai politik dalam negara demokratis. Menurut Miriam Budiardjo terdapat 4 fungsi partai politik yaitu (1) sebagai sarana komunikasi politik; (2) sebagai sarana sosialisasi politik; (3) sebagai sarana rekruitmen politik; dan (4) sebagai sarana pengatur konflik (conflict management) (Budiardjo, Miriam: 1989: 163).

Sebagai sarana komunikasi politik, partai politik menyalurkan aneka ragam pendapat dan aspirasi masyarakat dan mengaturnya sedemikian rupa sehingga kesimpangsiuran pendapat dalam masyarakat berkurang. Sebagai sarana sosialisasi politik, disamping menanamkan solidaritas dengan partai politik, partai politik juga mendidik anggota-anggotanya menjadi manusia yang sadar akan tang- 
gung jawabnya sebagai warga negara (Budiardjo, 1989: 163).

Sebagai sarana rekruitmen politik, partai politik berfungsi untuk mencari dan mengajak orang yang berbakat untuk turut aktif dalam kegiatan politik sebagai anggota partai (political recruitmen). Partai politik juga mengusahakan menarik golongan muda untuk dididik menjadi kader yang di masa datang akan mengganti pimpinan lama. Sebagai sarana pengatur konflik, dalam suasana demokrasi, perbedaan pendapat dalam masyarakat merupakan soal yang wajar sehingga apabila terjadi konflik, partai politik berusaha untuk mengatasinya (Miriam, 1989: 164).

Tidak dimungkinkannya calon perseorangan dalam pemilihan Presiden dan Wakil Presiden juga diperkuat oleh Mahkamah Konstitusi (MK). Beberapa putusan MK terkait pengujian Undang-Undang Nomor 23 Tahun 2003 tentang Pemilihan Umum Presiden dan Wakil Presiden dan Undang-Undang Nomor 42 Tahun 2008 tentang Pemilihan Umum Presiden dan Wakil Presiden (Undang-Undang Pemilihan presiden), menyatakan Pasal 6A ayat (2) UUD 1945 konstitusional.

MK dalam Putusan Nomor 007/PUUII/2004, Putusan Nomor 054/PUU-II/2004 dan Putusan Nomor 057/PUU-II/2004 perihal Pengujian Undang-Undang Nomor 23 Tahun 2003 terhadap Undang-Undang Dasar 1945 dalam pertimbangan hukumnya menyatakan bahwa untuk menjadi Presiden atau Wakil Presiden adalah hak setiap warga negara yang dijamin oleh konstitusi sesuai dengan ketentuan Pasal 27 ayat (1) dan Pasal 28D ayat (3) UUD 1945 sepanjang memenuhi persyaratan sebagaimana diatur dalam Pasal 6 dan Pasal 6A UUD 1945. Pasal 27 ayat (1) UUD 1945: Segala warga negara bersamaan kedudukannya di dalam hukum dan pemerintahan dan wajib menjunjung hukum dan pemerintahan itu dengan tidak ada kecualinya. Pasal 28D ayat (3) UUD 1945: Setiap warga negara berhak memperoleh kesempatan yang sama dalam pemerintahan. Dalam melaksanakan hak termaksud Pasal 6A ayat (2) UUD 1945 menentukan tata caranya yaitu harus diajukan oleh partai politik atau gabungan partai politik.

Diberikannya hak konstitusional untuk mengusulkan pasangan calon Presiden dan Wakil Presiden kepada partai politik oleh UUD 1945 bukanlah berarti hilangnya hak konstitusional warga negara untuk menjadi calon Presiden atau calon Wakil Presiden karena hal itu dijamin oleh UUD 1945, sebagaimana ditegaskan oleh Pasal 27 ayat (1) dan Pasal 28D ayat (3) UUD 1945 apabila warga negara yang bersangkutan telah memenuhi persyaratan yang ditentukan oleh Pasal 6 dan dilakukan menurut tata cara sebagaimana dimaksud oleh Pasal 6A ayat (2) UUD 1945. Persyaratan tersebut merupakan prosedur atau mekanisme yang mengikat terhadap setiap orang yang berkeinginan menjadi calon Presiden Republik Indonesia.

Melalui putusan Nomor 56/PUUVI/2008 dan Nomor 38/PUU-X/2012 perihal pengujian Undang-Undang Nomor 42 Tahun 2008 terhadap UUD 1945 MK menyatakan frasa "partai politik atau gabungan partai politik", dalam Pasal 6A ayat (2) UUD 1945 secara tegas bermakna bahwa hanya partai politik atau gabungan partai politiklah yang dapat mengusulkan Pasangan Calon Presiden dan Wakil Presiden dalam pemilihan umum Presiden dan Wakil Presiden. Dengan demikian, frasa dimaksud tidak memberi peluang adanya interpretasi lain, seperti menafsirkannya dengan kata-kata diusulkan oleh perseorangan (independen) apalagi pada saat pembicaraannya di MPR telah muncul wacana adanya Calon Presiden secara independen atau calon yang tidak diusulkan oleh partai politik atau gabungan partai politik, tetapi tidak disetujui oleh MPR.

Kehendak awal (original intent) para perumus perubahan UUD 1945 tentang Pasal 6A ayat (2) UUD 1945 sudah jelas bahwa "Pasangan Calon Presiden dan Wakil Presiden diusulkan oleh partai politik atau gabungan partai politik peserta pemilihan umum sebelum pelaksanaan pemilihan umum". Berdasarkan original intent tersebut, UUD 1945 hanya mengenal adanya pasangan calon Presiden dan calon Wakil Presiden yang diusulkan oleh partai politik atau gabungan partai politik peserta pemilihan umum, sehingga secara umum Undang-Undang pemilihan Presiden hanya merupakan pelaksanaan ketentuan Pasal 6A ayat (5) UUD 1945, 
yang menyatakan, "Tata cara pelaksanaan pemilihan Presiden dan Wakil Presiden lebih lanjut diatur dalam undang-undang". Lebih lanjut menurut MK konstruksi yang dibangun dalam konstitusi, bahwa pengusulan Pasangan Calon oleh partai politik atau gabungan Partai politik mencerminkan bahwa sistem politik yang dibangun mengacu pada sistem komunal/kolegial, bukan berlandaskan pada sistem individual (perseorangan).

MK menegaskan dalam pelaksanaan Pemilu setiap orang mempunyai hak dan dijamin untuk melaksanakan kedaulatannya tersebut untuk memilih Presiden dan Wakil Presiden, namun demikian untuk dipilih menjadi Presiden dan Wakil Presiden terdapat syarat-syarat yang dimuat dalam Pasal 6A ayat (2) UUD 1945, yang kemudian diatur lebih lanjut dalam Undang-Undang Pemilihan Presiden. Dengan demikian pembatasan tidak dapatnya calon perseorang maju dalam pemilihan Presiden oleh Undang-Undang Pemilihan Presiden bukanlah merupakan pengaturan yang diskriminatif. Apalagi jika dilihat ketentuan Pasal 1 ayat (2) UUD 1945 yang menjelaskan bahwa kedaulatan rakyat itu harus dilaksanakan menurut UUD 1945.

Mengenai gugatan bahwa tidak semua golongan masyarakat (golongan rakyat, golongan buruh, golongan petani, golongan kaum miskin kota, golongan fungsional seluruh rakyat Indonesia) terwadahi dalam partai politik maka MK melalui Putusan Nomor 4/PUU$\mathrm{XI} / 2013$ tentang Pengujian Undang-Undang Nomor 42 Tahun 2008 menyatakan Keberadaan partai politik sebagai wadah penyaluran aspirasi masyarakat sudah berlaku universal dan sudah menyediakan tempat terhadap golongan-golongan dalam masyarakat. Oleh sebab itu seharusnya golongan-golongan tersebut dapat menentukan pilihannya sendiri untuk bergabung ke dalam salah satu partai politik yang keberadaannya telah sah menurut undang-undang. Apabila pada saat ini golongan-golongan tersebut belum terwadahi kepentingannya dalam partai politik yang ada, maka golongan-golongan tersebut dapat membentuk partai politik sendiri sesuai dengan peraturan perundang-undangan.

Substansi yang kedua dari Pasal 6A ayat (2) UUD 1945 adalah memberi peluang kerjasama partai politik dalam mengusulkan pasangan calon Presiden dan calon Wakil Presiden. Keputusan ini dilandasai kesadaran para pengubah UUD 1945 yang memandang bahwa perlu menciptakan legitimasi Presiden dan Wakil Presiden yang terpilih dalam sistem multi partai (Caramani, 2008: 124)

Dalam kondisi multi partai legitimasi Presiden dan Wakil Presiden terpilih akan sulit terpenuhi. Permasalahan legitimasi pemilihan presiden bukanlah sekedar soal apakah dipilih langsung atau tidak, akan tetapi juga terkait dengan apakah presiden yang terpilih mendapat dukungan yang besar (minimal $50 \%$ lebih). Pilihan menerapkan sistem multipartai apabila presiden terpilih tidak memperoleh mayoritas suara dalam pemilihan langsung. Akan sangat riskan buat negara sebesar Indonesia yang sangat pluralis seandainya Presidennya hanya mendapat dukungan $25 \%$ suara, sedangkan pesaingnya $24 \%$.

Apabila dilakukan pemilihan Presiden secara langsung maka seharusnya ada penggabungan partai politik sampai hanya dua partai saja. Itu untuk memudahkan dalam pemenuhan $50 \%+1$ perolehan suara oleh Presiden terpilih. Penggabungan partai politik dalam mencalonkan diperlukan mengingat idealnya yang berhak mencalonkan Presiden dan Wakil Presiden adalah partai-partai yang mempunyai kursi besar di parlemen atau bisa juga partai yang tidak memperoleh banyak kursi di parlemen menggabungkan diri dengan partai lain untuk mencalonkan paket calon Presiden dan Wakil Presiden (Sekretariat Jenderal dan Kepaniteraan Mahkamah Konstitusi: 2010: 550).

Penggabungan ini konteksnya adalah pencalonan Presiden dan Wakil Presiden. Jadi sama sekali tidak mengganggu prinsipprinsip berdemokrasi bahkan dengan penggabungan supaya mencalonkan paket calon tertentu, memaksa setiap orang yang membentuk partai politik untuk memainkan politik dengan cara-cara yang rasional. Melalui prinsip semacam ini akan terjamin adanya sebuah sarana yang memungkinkan UndangUndang Pemilu memaksa partai-partai untuk mau ber-merger, menyatu apabila betul-betul secara rasional apabila sebuah partai politik tidak memiliki massa atau tidak mencuku- 
pi kekuatan di DPR (Sekretariat Jenderal dan Kepaniteraan Mahkamah Konstitusi: 2010: 550).

Dianalogikan, pada tahun 1999 Pemilu diikuti oleh 48 partai politik. Apabila dari 48 partai politik tersebut yang mengajukan Presiden dan Wakil Presiden ada sepuluh dan Presiden dan Wakil Presiden terpilih hanya mendapat $15 \%$, berarti yang tidak mendukung Presiden terpilih ada $85 \%$. Kondisi ini akan rawan menjadi sumber instabilitas dalam kehidupan bangsa. Oleh karena itu tanpa harus mengganggu sistem multipartai di Indonesia, diatur dua mekanisme agar Presiden terpilih memiliki legitimasi besar, yaitu dengan memberi peluang adanya putaran kedua dan disisi lain memberikan kesempatan dan mendorong partai politik melakukan kerjasama dalam mengusulkan/mencalonkan/mengusung pasangan calon Presiden dan calon Wakil Presiden.

Putaran kedua dilaksanakan apabila dalam pemilihan presiden tidak ada pasangan calon Presiden dan Wakil Presiden yang mendapatkan suara lebih dari lima puluh persen dari jumlah suara dalam pemilihan umum dengan sedikitnya dua puluh persen suara di setiap provinsi yang tersebar di lebih dari setengah jumlah provinsi di Indonesia sebagaimana sebagaimana ditetapkan oleh Pasal 6A ayat (3) UUD 1945. Pasal 6A ayat (4) UUD 1945 mengatur putaran kedua dalam Pemilihan presiden yaitu dalam hal tidak ada pasangan calon Presiden dan Wakil Presiden terpilih, dua pasangan calon yang memperoleh suara terbanyak pertama dan kedua dalam pemilihan umum dipilih oleh rakyat secara langsung dan pasangan yang memperoleh suara rakyat terbanyak dilantik sebagai Presiden dan Wakil Presiden.

Kerjasama antar partai politik dalam mengusulkan/mencalonkan/mengusung pasangan calon Presiden dan Wakil Presiden diperlukan agar Presiden dan Wakil Presiden terpilih memiliki legitimasi besar dan dapat menghindarkan pemilihan putaran kedua. Untuk menghindari putaran kedua melalui pencalonan Presiden dan Wakil Presiden yang diajukan gabungan partai politik diharapkan dapat dihasilkan suara terbanyak itulah yang akan terpilih menjadi Presiden dan
Wakil Presiden.

Melalui kerjasama antar partai politik maka pasangan calon Presiden dan Wakil Presiden yang maju telah terseleksi dengan baik karena gabungan partai politik diyakini akan melakukan seleksi yang mendalam sebelum mengajukannya. Mengingat apabila pasangan ini langsung diterjunkan kepada rakyat dan ternyata calon yang bersangkutan itu bermasalah, maka kalau pun mereka terpilih, maka tentu akan ada masalah-masalah yang sebetulnya menjadi masalah bangsa. Melalui kerjasama antar partai politik akan membantu masyarakat dalam melakukan selektivitas terhadap calon Presiden dan Wakil Presiden sesuai dengan persyaratan-persyaratan yang ada di dalam perumusan undang-undang maupun juga Undang-Undang Dasar, meskipun pada akhirnya rakyat yang berdaulatlah yang menentukan akhir dari Presiden siapa yang dikehendaki.

\section{c. Praktik Kerjasama antar Partai Politik dalam Pemilihan Presiden dan Wakil Presiden}

Terdapat dua undang-undang yang mengatur lebih lanjut mengenai kerjasama partai politik dalam pemilihan Presiden dan Wakil Presiden yaitu Undang-Undang Nomor 23 Tahun 2003 tentang pemilihan Presiden dan Wakil Presiden,yang kemudian karena dianggap sudah tidak sesuai dengan perkembangan demokrasi dan dinamika masyarakat dalam kehidupan berbangsa dan bernegara diganti dengan Undang-Undang Nomor 42 Tahun 2008 tentang Pemilihan presiden dan Wakil Presiden. Kedua UU ini dibentuk sebagai pelaksanaan ketentuan Pasal 6A ayat (5) yang menyatakan bahwa "tata cara pelaksanaan pemilihan Presiden dan Wakil Presiden lebih lanjut diatur dalam undang-undang".

Undang-Undang Nomor 23 Tahun 2003 menambahkan persyaratan yaitu pasangan calon Presiden dan Wakil Presiden hanya dapat diusulkan oleh partai politik atau gabungan partai politik yang memperoleh sekurang-kurangnya 15\% (lima belas persen) dari jumlah kursi DPR atau 20\% (dua puluh persen) dari perolehan suara sah secara nasional dalam Pemilu anggota DPR (Vide Pasal 5 ayat (4)). Ketentuan Peralihan Un- 
dang-Undang Nomor 23 Tahun 2003 yaitu Pasal 101 menentukan khusus untuk Pemilu Presiden dan Wakil Presiden tahun 2004 partai politik atau gabungan partai politik yang memenuhi persyaratan perolehan suara pada Pemilu anggota DPR sekurang-kurangnya 3\% (tiga persen) dari jumlah kursi DPR atau 5\% (lima persen) dari perolehan suara sah secara nasional hasil Pemilu anggota DPR tahun 2004 dapat mengusulkan Pasangan Calon.

Undang-Undang Nomor 42 Tahun

2008 juga kembali memberikan persyaratan bagi partai politik atau gabungan partai politik yang dapat mengajukan pasangan calon presiden dan wakil presiden memenuhi persyaratan perolehan kursi paling sedikit 20\% (dua puluh persen) dari jumlah kursi DPR atau memperoleh 25\% (dua puluh lima persen) dari suara sah nasional dalam Pemilu anggota DPR, sebelum pelaksanaan Pemilu Presiden dan Wakil Presiden (vide Pasal 9).

Ketentuan presidential threshold tersebut pernah diajukan pengujian ke MK. Pihak-pihak yang keberatan mendalilkan Pasal 9 Undang-Undang Pemilihan presiden yang mensyaratkan Partai politik atau Gabungan Partai politik yang mempunyai 20 persen kursi di DPR atau memperoleh 25 persen suara sah dalam pemilu adalah lebih bersifat pemberangusan, pengekangan, penjegalan, atau setidak-tidaknya distorsi resmi undangundang terhadap hak-hak politik warga negara dan melanggar hak asasi mansia yang dijamin UUD 1945. Rumusan pasal tersebut sangat diskriminatif dan mematikan kesempatan untuk diusulkan oleh partai politik atau gabungan partai politik dan penerapannya menimbulkan ketidakadilan.

MK melalui Putusan Nomor 51-52-59/ PUU-VI/2008 tentang pengujian UndangUndang Pemilihan Presiden menyatakan ketentuan Pasal 9 Undang-Undang Pemilihan Presiden tidak diskriminatif, karena untuk menentukan seseorang dapat diusulkan partai politik atau gabungan partai politik dalam pemilihan Presiden dan Wakil Presiden akan lebih ditentukan oleh rakyat dalam pemilu legislatif yang berlaku sama bagi semua calon presiden. Begitu juga syarat Perolehan suara 20 persen dari kursi DPR dan 25 persen suara sah nasional pemilu DPR tidak bertentangan dengan Pasal 6A ayat (5) UUD yang menentukan tata cara pelaksanaan pemilihan Presiden dan Wakil Presiden lebih lanjut diatur dalam Undang-Undang.

MK memandang Pasal 9 tersebut adalah kebijakan hukum yang terbuka (legal policy) yang didelegasikan oleh Pasal 6 A ayat (5) UUD 1945 dan tidak terkait dengan terlaksananya pemilihan umum yang demokratis, bebas, umum, rahasia, jujur dan adil. Syarat dukungan 20 persen kursi DPR dan 25 persen suara sah nasional, menurut MK merupakan dukungan awal yang juga ditentukan pemilih yang berdaulat yang membuktikan apakah partai politik mendapat dukungan rakyat. Dukungan yang sesungguhnya akan ditentukan oleh hasil pemilihan presiden kelak oleh rakyat melalui partai politik yang telah memperoleh dukungan tertentu melalui Pemilu.

Bahwa ketentuan dalam Pasal 9 Undang-Undang Pemilihan Presiden merupakan kebijakan hukum yang terbuka (legal policy) semakin dikukuhkan melalui putusan MK Nomor 108/PUU-XI/2013 tentang permohonan uji materi Undang-Undang Pemilihan Presiden yaitu penetapan ambang batas perolehan suara sebagai syarat pengajuan calon Presiden dan calon Wakil Presiden merupakan kewenangan DPR sebagai pembentuk undang-undang. Ketentuan ambang batas tersebut merupakan kebijakan hukum terbuka atau delegasi kewenangan terbuka yang dapat ditentukan sebagai legal policy oleh pembentuk undang-undang dengan tetap mendasarkan pada ketentuan UUD 1945.

Pemilihan Presiden secara langsung pertama kali digelar pada tahun 2004. Idealnya, Undang-Undang Pemilu sudah disahkan setidaknya dua tahun sebelum hari-H pelaksanaan pemilu sehingga KPU dan jajarannya mempunyai waktu yang cukup untuk mempersiapkannya. Namun, akibat tarik-menarik politik yang kuat di DPR Undang-Undang Nomor 23 Tahun 2003 tentang Pemilihan Umum Presiden dan Wakil Presiden (diundangkan pada 31 Juli 2003. Itu artinya KPU hanya punya waktu 13 bulan juga untuk menyiapkan pemilu presiden (Santoso dkk., 2006: 44).

Pemilihan Presiden 2004 tidak bisa di- 
Tabel 1. Perolehan suara dan kursi tiap Partai politik

\begin{tabular}{|c|c|c|c|c|}
\hline No & Partai & Jumlah suara & \% suara & Kursi \\
\hline 1 & $\begin{array}{l}\text { Partai Nasional Indonesia Marhae- } \\
\text { nisme }\end{array}$ & 906,739 & 0,80 & 1 \\
\hline 2 & Partai Buruh Sosial Demokrat & 634,515 & 0,56 & 0 \\
\hline 3 & Partai Bulan Bintang & 2.965 .040 & 2,62 & 11 \\
\hline 4 & Partai Merdeka & 839,705 & 0,74 & 0 \\
\hline 5 & Partai Persatuan Pembangunan & 9.226 .444 & 8,16 & 58 \\
\hline 6 & $\begin{array}{l}\text { Partai Persatuan Demokrasi Kebang- } \\
\text { saan }\end{array}$ & 1.310 .207 & 1,16 & 4 \\
\hline 7 & Partai Perhimpunan Indonesia Baru & 669,835 & 0,59 & 0 \\
\hline 8 & Partai Nasional Banteng Kemerdekaan & 1.228 .497 & 1,09 & 0 \\
\hline 9 & Partai Demokrat & 8.437 .868 & 7,46 & 55 \\
\hline 10 & $\begin{array}{l}\text { Partai Keadilan dan Persatuan Indo- } \\
\text { nesia }\end{array}$ & 1.420 .085 & 1,26 & 1 \\
\hline 11 & Partai Penegak Demokrasi Indonesia & 844,48 & 0,75 & 1 \\
\hline 12 & $\begin{array}{l}\text { Partai Persatuan Nahdlatul Ummah } \\
\text { Indonesia }\end{array}$ & 890,98 & 0,79 & 0 \\
\hline 13 & Partai Amanat Nasional & 7.255 .331 & 6,41 & 53 \\
\hline 14 & Partai Karya Peduli Bangsa & 2.394 .651 & 2,12 & 2 \\
\hline 15 & Partai Kebangkitan Bangsa & 12.002 .885 & 10,61 & 52 \\
\hline 16 & Partai Keadilan Sejahtera & $8.149 . .457$ & 7,20 & 45 \\
\hline 17 & Partai Bintang Reformasi & 2.944 .529 & 2,60 & 14 \\
\hline 18 & $\begin{array}{l}\text { Partai Demokrasi Indonesia Perjuan- } \\
\text { gan }\end{array}$ & 20.710 .006 & 18,31 & 109 \\
\hline 19 & Partai Damai Sejahtera & 2.424 .319 & 2,14 & 13 \\
\hline 20 & Partai Golongan Karya & 24.461 .104 & 21,62 & 128 \\
\hline 21 & Partai Patriot Pancasila & 1.178 .738 & 1,04 & 0 \\
\hline 22 & Partai Sarikat Indonesia & 677,259 & 0,60 & 0 \\
\hline 23 & Partai Persatuan Daerah & 656,473 & 0,58 & 0 \\
\hline 24 & Partai Pelopor & 896,603 & 0,79 & 3 \\
\hline Total & & 113.125 .750 & 100,00 & 550 \\
\hline
\end{tabular}

Sumber: Komisi Pemilihan Umum (KPU): 2010: 43

lepaskan dari hasil pemilu 2004 untuk memilih anggota DPR yang dilaksanakan pada tanggal 5 April 2004 dan diikuti 24 Partai politik peserta Pemilu, ternyata hanya menghasilkan 16 Partai politik yang memperoleh kursi di DPR. Adapun perolehan suara dan kursi tiap Partai politik pada Gambar 1.

Sesuai persyaratan hanya partai politik atau gabungan partai politik yang memenuhi persyaratan perolehan suara pada Pemilu anggota DPR sekurang-kurangnya 3\% (tiga persen) dari jumlah kursi DPR atau 5\% (lima persen) dari perolehan suara sah secara nasional hasil Pemilu anggota DPR tahun 2004 dapat mengusulkan Pasangan Calon, maka sejumlah partai politik melakukan kerjasama dalam pemilihan Presiden 2004. Pemilihan presiden 2004 diikuti oleh 5 Pasang calon yaitu Wiranto-Salahuddin Wahid diajukan oleh partai golkar PPNUI, Partai Patriot, dan PDK; Megawati Soekarnoputri-Hasyim Muzadi diajukan oleh PDI Perjuangan dan PDS; M. Amien Rais-Siswono Yudohusodo diajukan oleh PAN, PKS, PBR, PSI, PBSD, PNBK, PPDI, dan PNI Marhaenisme; Susilo Bambang Yudhoyono-Muhammad Jusuf Kalla dicalonkan oleh Partai Demokrat, PBB, dan PKP Indonesia; dan Hamzah Haz-Agum Gumelar diajukan oleh PPP

Hasil Pemilu Presiden dan Wakil Presiden tahun 2004 putaran I (pertama) yang diikuti sebanyak 5 pasangan, yang dilaksa- 
Tabel 2. Hasil Pemilu Presiden dan Wakil Presiden tahun 2004 putaran I (pertama)

\begin{tabular}{|c|c|c|c|}
\hline $\mathrm{No}$ & Nama Pasangan & Perolehan Suara & Persentase \\
\hline 1 & $\begin{array}{l}\text { Wiranto } \\
\text { Salahuddin Wahid }\end{array}$ & 23.827.512 & $22.19 \%$ \\
\hline 2 & $\begin{array}{l}\text { Megawati Soekarnoputri } \\
\text { Ahmad Hasyim Muzadi }\end{array}$ & 28.186 .780 & $26.24 \%$ \\
\hline 3 & $\begin{array}{l}\text { M. Amien Rais } \\
\text { Siswono Yudo Husodo }\end{array}$ & 16.042 .105 & $14.94 \%$ \\
\hline 4 & $\begin{array}{l}\text { Susilo Bambang Yudhoyono dan } \\
\text { Muhammad Jusuf Kalla }\end{array}$ & 36.070 .622 & $33.58 \%$ \\
\hline 5 & $\begin{array}{l}\text { Hamzah Haz } \\
\text { Agum Gumelar }\end{array}$ & 3.276 .001 & $13.05 \%$ \\
\hline
\end{tabular}

Sumber: Komisi Pemilihan Umum (KPU): 2010: 44

Tabel 3. Hasil akhir perolehan suara dalam Pemilihan presiden putaran II (kedua)

\begin{tabular}{llll}
\hline No & Nama Pasangan & Perolehan Suara & Persentase \\
\hline 2 & $\begin{array}{l}\text { Megawati Soekarnoputri } \\
\text { Ahmad Hasyim Muzadi }\end{array}$ & 44.990 .704 & $39,38 \%$ \\
\hline 4 & $\begin{array}{l}\text { Susilo Bambang Yudhoyono } \\
\text { Muhammad Jusuf Kalla }\end{array}$ & 69.266 .350 & $60,62 \%$ \\
\hline
\end{tabular}

Sumber: Komisi Pemilihan Umum (KPU): 2010: 44

nakan serentak pada tanggal 5 Juli 2004 pada Gambar 2.

Mengingat kelima pasangan calon presiden dan wakil presiden peserta Pemilu Presiden dan wakil presiden putaran I (pertama) belum ada yang memperoleh suara lebih dari 50\%, maka dilakukan pemilu Presiden dan Wakil Presiden putaran II (kedua), dengan peserta dua calon Presiden dan calon Wakil Presiden yang memperoleh suara terbanyak pertama dan terbanyak kedua yaitu Susilo Bambang Yudhoyono-Muhammad Jusuf Kalla berhadapan dengan Megawati Soekarnoputri - Hasyim Muzadi.

Memasuki Pemilihan presiden putaran kedua terdapat perubahan dukungan antar Partai politik, beberapa Partai politik yang calon Presiden dan calon Wakil Presidennya tidak terpilih di putaran sebelumnya bergabung menjadi pendukung calon Presiden dan calon Wakil Presiden yang masuk ke putaran kedua. Pasangan Megawati SoekarnoputriHasyim Muzadi di putaran kedua didukung oleh PDI Perjuangan, Partai Golkar, PPP, PDS, PBR, PKPB, dan PNI Marhaenisme. Pasangan Susilo Bambang Yudhoyono-Muhammad Ju- suf Kalla memasuki putaran kedua didukung oleh Partai Demokrat, PBB, dan PKP Indonesia, PKS, PPDK, Partai Pelopor, PPDI.

Hasil akhir perolehan suara dalam Pemilihan presiden putaran II (kedua) yang dilaksanakan pada tanggal 20 September 2004 pada Tabel 3.

Terhadap bentuk kerjasama Partai politik dalam Pemilihan presiden tahun 2004 terdapat catatan yaitu fenomena pergeseran peta kerjasama dan pola persebaran partai politik dari kerjasama menjelang putaran pertama ke kerjasama menjelang Pemilihan presiden putaran kedua terjadi secara tidak beraturan. Kerjasama pendukung Amien Rais-Siswono Yudohusodo, misalnya terbelah menjadi dua. PBR dan PNI Marhaenisme bergabung di kerjasama yang mendukung Megawati- Hasyim Muzadi, sedangkan PKS bergabung dengan kerjasama partai pendukung pasangan Susilo Bambang YudhoyonoMuhammad Jusuf Kalla (Yuda, 2010:164).

Gejala politik ini menunjukkan kerjasama antar partai politik yang terbangun sangat cair dan rapuh. Kerjasama yang terbangun lebih berdasarkan pertimbangan pragmatism 
Tabel 4. Hasil perolehan suara Partai politik yang Berhasil Lolos dari Parliamentary Threshold dan Perolehan Kursi dalam DPR

\begin{tabular}{lllll}
\hline No & Nama Partai & Suara & Persentase & Kursi \\
\hline 1 & Partai Demokrat & 21.655 .295 & 20,81 & 148 \\
2 & Partai Golongan Karya & 15.031 .497 & 14,45 & 106 \\
3 & Partai Demokrasi Indonesia Perjuangan & 14.576 .388 & 14,01 & 94 \\
4 & Partai Keadilan Sejahtera & 8.204 .946 & 7,89 & 57 \\
5 & Partai Amanat Nasional & 6.273 .462 & 6,03 & 46 \\
6 & Partai Persatuan Pembangunan & 5.544 .332 & 5,33 & 38 \\
7 & Partai Kebangkitan Bangsa & 5.146 .302 & 4,95 & 28 \\
8 & Partai Gerakan Indonesia Raya & 4.642 .795 & 4,46 & 26 \\
9 & Partai Hati Nurani Rakyat & 3.925 .620 & 3,77 & 17 \\
\hline
\end{tabular}

Sumber: Komisi Pemilihan Umum (KPU): 2010: 45

Tabel 5. Pemilihan presiden dan wakil presiden pada tahun 2009

\begin{tabular}{llcc}
\hline No & $\begin{array}{l}\text { Nama Pasangan Calon Presiden dan } \\
\text { Wakil Presiden }\end{array}$ & $\begin{array}{c}\text { Perolehan } \\
\text { Suara }\end{array}$ & $\begin{array}{c}\text { Persentase } \\
(\%)\end{array}$ \\
\hline 1 & Megawati Soekarnoputri-Prabowo Subianto & 32.548 .105 & 26.79 \\
2 & Susilo Bambang Yudhoyono-Boediono & 73.874 .562 & 60.80 \\
3 & Muhammad Jusuf Kalla-Wiranto & 15.081 .814 & 12.41 \\
\hline
\end{tabular}

Sumber: Komisi Pemilihan Umum (KPU): 2010: 46

politik jangka pendek ketimbang atas dasar kedekatan ideologi atau persamaan platform politik (Yuda, 2010:164).

Indonesia menggelar Pemilihan presiden secara langsung untuk kedua kalinya pada tahun 2009. Pemilu Presiden dan Wakil Presiden sangat dipengaruhi oleh hasil pemilu untuk memilih anggota DPR tahun 2009 yang dilaksanakan pada tanggal 9 April 2009 dengan diikuti oleh 38 Partai Nasional. Hasil perolehan suara Partai politik yang Berhasil Lolos dari Parliamentary Threshold dan Perolehan Kursi dalam DPR pada Gambar 4. Pemilihan presiden 2009 diikuti tiga pasangan calon Presiden dan calon Wakil Presiden, yaitu, pertama, Megawati Soekarnoputri-Prabowo Soebianto diusung oleh kerjasama sembilan Partai politik. Dua Partai politik yang lolos parliamentary threshold (PDIP dan Gerindra) dan tujuh partai nonparlemen (Partai Merdeka, Partai PNI Marhaen, PKP, Kedaulatan, PSI, Partai Buruh, dan PPNUI). Kedua, Susilo Bambang Yudhoyono-Boediono didukung oleh kerjasama 23 Partai politik yang terdiri atas lima Partai politik yang lolos ke parlemen (Partai Demokrat, PKS, PPP, PAN, dan PKB), serta 18 Partai politik nonparlemen (PBB, PBR, PDS, PKPI, PKPB, Patriot, PNBKI, PPI, PPRN, PDP, PPPI, Partai Republikan, Pelopor, PKDI, PIS, PPIB, dan PPDI, PPD). Ketiga, Jusuf Kalla-Wiranto didukung oleh kerjasama dua Partai politik lolos parliamentary threshold, yaitu Partai Golkar dan Hanura, serta beberapa partai kecil yang tidak lolos parliamentary threshold.

Pemilihan presiden dan wakil presiden pada tahun 2009 dimenangkan pasangan nomor urut 2, Susilo Bambang YudhoyonoBoediono dalam satu putaran dengan memperoleh suara lebih dari 60 persen.

Terdapat catatan penting mengenai peta kerjasama pemilihan Presiden 2009 yang dimenangkan pasangan Susilo Bambang Yudhoyono-Boediono yaitu rendahnya pertimbangan ideologi dan platform partai politik dalam menentukan kebijakan kerjasama. Pertimbangan pragmatisme politik dan peluang meraih kekuasaan jauh lebih besar ketimbang alasan persamaan platform dan ideologi. Fenomena ini menunjukkan lemahnya ideologi partai dalam bekerjasama. Hal inilah akan menyebabkan bangunan kerjasama yang terbentuk sangat rapuh, pragmatis dan tidak disiplin (The Indonesian Institute: 
2010: 89)

Meskipun kerjasama partai pengusung pasangan Susilo Bambang Yudhoyono -Boediono di atas kertas telah menguasai mayoritas sederhana kekuatan parlemen - 314 kursi di DPR terdiri dari Partai Demokrat 148 kursi, PKS 57, PAN 46, PPP 38, dan PKB 28 - sebesar 56,56 persen dari 560 kursi DPR, namun Susilo Bambang Yudhoyono-Boediono memperluas kerjasama dengan merangkul Partai Golkar bergabung dalam kerjasama pendukung pemerintah. Opsi ini memperluas kekuatan kerjasama dengan menguasai 75,48 persen kursi di parlemen. Argumentasinya adalah kuantitas kekuatan kerjasama partai pendukung pemerintah sebesar 56 persen dipandang Susilo Bambang Yudhoyono dan Partai Demokrat masih belum cukup untuk mengamankan posisi pemerintah. Kendatipun secara matematis 56 persen kursi di parlemen sudah mencapai mayoritas sederhana atau kerjasama kemenangan minimal (minimal winning coalition), tetapi jumlah itu dipandang belum mampu mengamankan kebijakan pemerintah di parlemen (The Indonesian Institute: 2010: 91).

Kerjasama yang tidak dibangun atas dasar platform dan ideologi mengakibatkan kinerja pemerintah Susilo Bambang Yudhoyono-Boediono menjadi kurang efektif dan pemerintahan tersandera secara politik. Sumbatan politik yang menyendera jalannya pemerintahan adalah politik akomodatif yang dijalankan Pemerintahan Susilo Bambang Yudhoyono dalam membangun legitimasi politik, politik kompromi yang melahirkan kabinet kompromi partai-partai, serta pollitik transaksional yang menjadi basis relasi partai-partai mitra kerjasama (The Indonesian Institute: 2010: 4).

Politik akomodatif yang sangat mementingkan keseimbangan dan harmoni politik menyebabkan pemerintahan Susilo Bambang Yudhoyono-Boediono cenderung merangkul dan memuaskan semua kalangan dengan keinginan mengakomodasi semua partai dalam pemerintahan. Politik Akomodatif ini cenderung tidak menghendaki adanya "opisisi" dan membutuhkan pengamanan (sekuritas) politik yang berlebihan dengan membangun kerjasama sebesar-besarnya. Kerjasama kebesaran dengan persilangan kepentingan yang luas seperti ini menyebabkan pemerintah tersandera kepentingan partai-partai (The Indonesian Institute: 2010: 5).

\section{d. Membangun Kerjasama Partai Politik berbasis Konstitusi}

Praktik kerjasama partai politik dalam pemilihan presiden selama ini (2004 dan 2009) ternyata masih belum sesuai dengan kehendak awal (original intent) para perumus perubahan UUD 1945. Bahkan praktik ini potensial diteruskan dalam pemilihan presiden 2014. Kembali terjadi pembentukan kerjasama politik "gendut" sebagaimana dilakukan oleh salah satu pasangan calon Presiden dan calon Wakil Presiden yang mengulangi karakter kerjasama bentukan pemerintahan sebelumnya yaitu perkumpulan dengan nuansa transaksional. Partai Gerindra dengan perolehan suara pemilu legislatif 2014 sebesar 11,81\% dalam mengusung calon Presiden dan calon Wakil Presiden Prabowo SubiantoHatta Rajasa bekerjasama dengan banyak partai seperti PKS, PPP, PAN, Partai Golkar dan PBB sehingga mendapatkan dukungan suara Pemilu legislatif sebesar $49 \%$,nyaris dua kali lipat syarat pencalonan Presiden dan Wakil Presiden (Majalah Tempo: 2014: 32)

Kerjasama yang dibangun dengan semangat merekrut partai politik mana saja yang bersedia ikut dalam gerbong kerjasama. Strategi tebar jala selebar-lebarnya ini didasari pertimbangan bahwa semakin banyak partai politik yang terlibat semakin besar peluang menang. Strategi ini menunjukkan ideologi partai politik tak lagi penting. Lebih jauh ideologi partai politik tidak lagi penting. Lebih jauh lagi, ideologi tampaknya tak lebih dari sekedar make-up untuk memikat pemilih. PAN sebagai partai dengan platform pluralis, misalnya bergabung dengan Gerindra yang dalam manifestonya mengagendakan pemurnian agama (Majalah Tempo: 2014: 32).

UUD 1945 menghendaki kerjasama partai politik dalam pencalonan Presiden dan Wakil Presiden diletakkan dalam dua prinsip besar yaitu: pertama, kerjasama Partai politik diharapkan melahirkan kerjasama jangka panjang yang dapat melahirkan penyeder- 
hanaan partai politik secara alamiah. Kedua, kerjasama partai politik dalam pemilihan Presiden haruslah dikaitkan dengan rancang bangun sistem pemerintahan menurut UUD 1945, yaitu sistem pemerintahan presidensial yang menjadi salah satu di antara kesepakatan MPR saat melakukan pembahasan Perubahan UUD 1945.

Mengenai prinsip yang pertama, dapat dilihat pendapat Soewarno sebagai salah satu anggota Panitia Ad Hoc I Badan Pekerja MPR RI yang mempersiapkan draft perubahan UUD 1945 yang mengemukakan “... Yaitu bahwa mengapa kami mengusulkan? Menjelang pemilu itu satu partai politik boleh mengajukan sepasang calon, tetapi juga boleh beberapa partai politik bersepakat mengajukan sepasang calon. Ide dasarnya adalah bahwa kita ingin adanya penyederhanaan sistem politik sebagaimana memang itu kita kehendaki semua. Karena banyaknya partai juga satu segi memang lebih menjamin demokrasi, tetapi segi lain juga merupakan kelemahan tersendiri yaitu instabilitas" (Sekretariat Jenderal dan Kepaniteraan Mahkamah Konstitusi: Buku IV: 406)

Diterangkan lebih lanjut “...boleh juga beberapa partai membuat pasangan Presiden dan Wakil Presiden. Ini punya nilai tinggi dalam artian mendorong penyederhanaan kehidupan kepartaian secara wajar dan alamiah. Dan ini kalau sudah terjadi kelompok-kelompok semacam itu maka secara alamiah terjadi penyederhanaan kepartaian di Indonesia ini, tidak terlalu banyak seperti yang berkembang" (Sekretariat Jenderal dan Kepaniteraan Mahkamah Konstitusi: Buku IV: 349)

Prinsip yang pertama ini dapat tercapai apabila kerjasama antar partai politik didasarkan pada persamaan garis perjuangan partai politik dengan menghindari terjadinya negosiasi dan tawar menawar (bargaining) politik yang bersifat taktis demi kepentingan sesaat, sehingga tercipta negosiasi dan kerjasama strategis partai politik untuk kepentingan jangka panjang. Hal demikian akan lebih memungkinkan bagi penggabungan partai politik secara alamiah dan strategis sehingga dalam jangka panjang akan lebih menjamin penyederhanaan Partai politik. Dalam kerangka itulah ketentuan Pasal 6A ayat (2)
UUD 1945 harus dimaknai (Lihat pertimbangan hukum 3.17 Putusan MK Nomor 14/ PUU-XI/2013 tentang Pengujian UndangUndang Pemilihan presiden).

Kesamaan ide dan progam dalam kerjasama partai politik untuk mengajukan calon Presiden dan Wakil Presiden merupakan suatu keharusan dikarenakan perubahan UUD 1945 telah mengakibatkan terjadinya perubahan dalam pengelolaan pembangunan di Indonesia yaitu dengan tidak dibuatnya lagi Garis-Garis Besar Haluan Negara (GBHN) oleh MPR sebagai pedoman penyusunan rencana pembangunan nasional. Pasal 3 UUD 1945 sebelum perubahan berbunyi: Majelis Permusyawaratan Rakyat menetapkan Undang-Undang Dasar dan garis-garis besar daripada haluan negara. Pasal 3 UUD 1945 setelah perubahan berbunyi: ayat (1): Majelis Permusyawaratan Rakyat berwenang mengubah dan menetapkan Undang-Undang Dasar, ayat (2): Majelis Permusyawaratan Rakyat melantik Presiden dan/atau Wakil Presiden, ayat (3): Majelis Permusyawaratan Rakyat hanya dapat memberhentikan Presiden dan/atau Wakil Presiden dalam masa jabatannya menurut Undang-Undang Dasar.

Sebagai pengganti GBHN sesuai ketentuan Undang-Undang Nomor 25 Tahun 2004 tentang Sistem Perencanaan Pembangunan Nasional kepada Presiden dan Wakil Presiden diberikan tugas dan tanggung jawab untuk menyusun arah dan strategi pembangunan Nasional selama 5 tahun dalam sebuah dokumen perencanaan yang disebut Rencana Pembangunan Jangka Menengah (RPJM) Nasional. RPJM Nasional merupakan penjabaran dari visi, misi, dan program Presiden dan Wakil Presiden yang penyusunannya berpedoman pada visi ideal, yaitu cita-cita luhur sebagaimana termaktub dalan Pembukaan UUD 1945 dan Rencana Pembangunan Jangka Panjang (RPJP) Nasional yang telah ditetapkan dengan Undang-Undang Nomor 17 Tahun 2007 tentang RPJP Nasional 20052025.

Hal ini juga selaras dengan salah satu persyaratan calon Presiden dan Wakil Presiden sebagaimana ditentukan dalam Pasal ke 5 huruf $r$ Undang-Undang Pemilihan Presiden yaitu memiliki visi, misi, dan program 
dalam melaksanakan pemerintahan negara Republik Indonesia. Kemudian Pasal 15 huruf e Undang-Undang Pemilihan Presiden mengatur partai politik atau gabungan partai politik dalam mendaftarkan bakal pasangan calon ke KPU wajib menyerahkan naskah visi, misi, dan program dari bakal pasangan calon. Dalam Penjelasan Pasal 15 huruf e Undang-Undang Pemilihan Presiden: "Visi, misi dan program strategis bakal pasangan calon dibuat berdasarkan prinsip bahwa Presiden Republik Indonesia memegang kekuasaan pemerintahan menurut Undang-Undang Dasar sebagaimana diatur dalam Pasal 4 ayat (1) Undang-Undang Dasar Negara Republik Indonesia Tahun 1945, serta merupakan penjabaran dari peraturan perundangundangan".

Visi dan misi dan progam pasangan calon sesuai ketentuan Pasal 37 ayat (1) Undang-Undang Pemilihan Presiden merupakan materi kampanye pasangan calon, dalam Penjelasan Pasal 37 ayat (1) Undang-Undang Pemilihan Presiden visi dan misi pasangan calon harus mengacu pada Rencana Pembangunan Jangka Panjang (RPJP) Nasional sebagaimana diatur dalam Undang-Undang Nomor 17 Tahun 2007 tentang Rencana Pembangunan Jangka Panjang Nasional Tahun 2005-2025 dan harus dapat dijabarkan dalam program kerja pemerintah apabila pasangan calon tersebut terpilih. Hal ini agar tercermin dalam Rencana Pembangunan Jangka Menengah (RPJM) Nasional dan Rencana Kerja Pemerintah (RKP) yang merupakan rencana kerja tahunan sebagaimana diatur dalam Undang-Undang Nomor 25 Tahun 2004 tentang Sistem Perencanaan Pembangunan Nasional.

Mengingat betapa strategisnya kedudukan visi dan misi pasangan calon, maka menjadi kewajiban bagi siapapun calon Presiden dan calon Wakil Presiden untuk menyatukan visi dan misi, dimana penyatuan visi dan misi tersebut harus dilandasi terlebih dahulu oleh penyamaan ide dan progam partai politik pengusungnya. Kerjasama antara partai politik harus dilakukan hati-hati mengingat tidak bisa hanya didasarkan pada pertimbangan kepentingan praktis semata yaitu hanya agar bisa maju dalam kontestasi pemilihan pre- siden tanpa menakar ide dan progam yang dimiliki masing-masing partai politik karena hal tersebut akan menyulitkan penyusunan visi dan misi calon Presiden dan calon Wakil Presiden.

Melalui model penyatuan ide dan progam antar partai politik ini diyakini akan membuat kerjasama partai politik menjadi lebih kuat sifatnya dibandingkan kerjama yang dilakukan yang didasarkan hanya kepada bagi-bagi jabatan menteri. Ketentuan Pasal 6A ayat (2) Perubahan Ketiga UUD 1945 memberi kesempatan pada gabungan partai politik untuk mengajukan calon Presiden dan Wakil Presiden, agar kerjasama tersebut tidak mengandung potensi instabilitas politik maka kerjasama partai politik harus dilakukan oleh partai politik yang memiliki kesamaan pandangan, sehingga kesepakatan antar-partai politik tersebut menghapus potensi instabilitas tersebut .

Prinsip yang kedua yaitu kerjasama partai politik dalam pemilihan presiden haruslah dikaitkan dengan rancang bangun sistem pemerintahan presidensial. Penegasan sistem pemerintahan presidensial dipilih mengingat dipandang lebih cocok untuk diterapkan di Indonesia, sebab pada saat Indonesia menerapkan sistem pemerintahan parlementer yang dimulai dengan adanya Maklumat Pemerintah 14 November 1945 mengenai susunan kabinet baru yang dipimpin oleh Perdana Menteri Sutan Sjahrir dan diakhiri oleh kabinet Perdana Menteri Djuanda Kartawidjaja Tahun 1959, praktik penyelenggaraan kehidupan bernegara kurang stabil. Dalam Maklumat Pemerintah tanggal 14 Nopember 1945 mengenai sistem penyelenggaraan pemerintah negara yaitu perubahan sistem pemerintahan menjadi sistem Parlementer. Perubahan tersebut terjadi setelah Badan Pekerja mengusulkan kepada presiden adanya sistem pertanggungjawaban menteri-menteri kepada parlemen, yaitu Komite Nasional Indonesia Pusat. Jika semula kabinet berada dibawah presiden maka dengan keluarnya maklumat pemerintah tanggal 14 Nopember 1945, kedudukan kabinet berada di bawah perdana menteri (Suny, Ismail: 1983: 30).

Pertimbangan lainnya didasarkan pada pilihan para pendiri negara Indonesia yang 
menetapkan negara demokrasi dengan sistem pemerintahan presidensial. Pilihan pendiri bangsa ini diwujudkan, pertama, Presiden memegang kekuasaan pemerintahan menurut Undang-Undang Dasar (Pasal 4 ayat (1) UUD 1945 sebelum perubahan). Kedua, UUD 1945 sebelum perubahan tidak memuat ketentuan Presiden bertanggung jawab kepada DPR. Ketiga, menteri-menteri tidak bertanggungjawab kepada DPR melainkan sebagai pembantu Presiden kedudukannya tergantung kepada Presiden.

Penegasan sistem pemerintahan presidensial mengandaikan adanya lembaga kepresidenan yang mempunyai legitimasi kuat yang dicirikan dengan (1) adanya masa jabatan Presiden yang bersifat tetap (fixed term); (2) Presiden selain sebagai kepala negara juga kepala pemerintahan; (3) adanya mekanisme saling mengawasi dan mengimbangi (checks and balances); dan (4) adanya mekanisme impeachment (Sekretariat Jenderal dan Kepaniteraan MK: 2005: 2). Sebagai konsekuensi dari penegasan sistem pemerintahan presidensial maka UUD 1945 setelah perubahan memuat ketentuan tambahan sebagai berikut, Pertama, Presiden dan Wakil Presiden dipilih dalam satu pasangan secara langsung oleh rakyat (Pasal 6A ayat (1)).

Kedua, masa jabatan Presiden dan Wakil Presiden adalah tetap selama 5 tahun dalam arti Presiden dan/atau Wakil Presiden tidak dapat diberhentikan selama masa jabatannya hanya karena alasan politis dan kebijakan. Presiden dan/atau Wakil Presiden hanya dapat dijatuhkan dengan alasan-alasan tertentu yang harus dibuktikan lebih dulu secara hukum atas usul DPR setelah mendapat putusan hukum dari Mahkamah Konstitusi (Pasal 7A dan 7B). Ketiga, Presiden tidak dapat membekukan dan/atau membubarkan DPR (Pasal 7C).

Menurut pendapat Aren Lijphart dalam sistem pemerintahan presidensial kedudukan Presiden tidak bergantung kepada parlemen karena Presiden tidak bertanggung jawab kepada parlemen, melainkan presiden bertanggung jawab kepada konstitusi (Lijphart, Arend: 2002: 11). Mengingat sistem pemerintahan presidensial di Indonesia memiliki karakteristik yaitu: pertama, sebagai konse- kuensi kemajemukan aliran politik di Indonesia, parlemen khususnya DPR terdiri dari perwakilan multi partai; dan kedua, banyaknya fungsi Presiden dan fungsi DPR yang pelaksanaannya mengharuskan kerjasama keduanya, maka siapapun Presiden dan Wakil Presiden terpilih harus bekerjasama dengan DPR. Menurut UUD 1945, dalam hal tertentu kebijakan Presiden harus memperhatikan pertimbangan DPR seperti pengangkatan duta dan penerimaan duta dari negara lain.

Presiden dalam menyatakan perang, membuat perdamaian dan perjanjian dengan negara lain, serta perjanjian internasional yang menimbulkan akibat luas dan mendasar bagi kehidupan rakyat yang terkait dengan beban keuangan negara dan/atau mengharuskan perubahan atau pembentukan Undang-Undang harus dengan persetujuan DPR. Pada sisi lain, DPR dalam menjalankan kekuasaan membentuk Undang-Undang harus dilakukan bersama-sama serta disetujui bersama dengan Presiden. Mengenai Anggaran Pendapatan dan Belanja Negara (APBN), Presiden mengajukan rancangan $\mathrm{APBN}$ untuk dibahas bersama untuk mendapat persetujuan DPR dan apabila rancangan APBN tidak mendapatkan persetujuan DPR, Presiden menjalankan APBN tahun sebelumnya. Maka menjadi keharusan bagi Presiden dan Wakil Presiden terpilih untuk bekerjasama dengan DPR yang berarti kerjasama dengan Partai politik dalam DPR.

Kerjasama Presiden dengan DPR harus diletakkan dalam pemahaman posisi Presiden secara umum tidak tergantung pada ada atau tidak adanya dukungan DPR sebagaimana lazimnya yang berlaku dalam sistem pemerintahan parlementer. Hanya untuk tindakan dan beberapa kebijakan tertentu saja tindakan Presiden harus dengan pertimbangan atau persetujuan DPR. Walaupun dukungan DPR sangat penting untuk efektivitas jalannya pemerintahan yang dilakukan Presiden tetapi dukungan tersebut tidaklah mutlak (Lihat pertimbangan hukum 3.17 Putusan MK Nomor 14/PUU-XI/2013 tentang Pengujian Undang-Undang Pemilihan presiden.).

Menurut UUD 1945, seluruh anggota DPR dipilih melalui mekanisme pemilihan umum yang pesertanya diikuti oleh partai po- 
litik, sehingga anggota DPR pasti anggota partai politik. Oleh karena konfigurasi kekuatan DPR, berkaitan dengan konfigurasi kekuatan partai politik yang memiliki anggota di DPR, maka posisi partai politik yang memiliki kursi di DPR dalam sistem pemerintahan Indonesia adalah penting dan dapat mempengaruhi efektivitas pelaksanaan kebijakan pemerintahan oleh Presiden. Walaupun demikian, Presiden dalam menjalankan kekuasaan pemerintahan tidak tergantung sepenuhnya pada ada atau tidak adanya dukungan partai politik, karena Presiden dipilih langsung oleh rakyat, maka dukungan dan legitimasi rakyat itulah yang seharusnya menentukan efektivitas kebijakan pemerintahan yang dilakukan oleh Presiden (Lihat pertimbangan hukum 3.17 Putusan MK Nomor 14/PUU-XI/2013 tentang Pengujian UU Pemilihan presiden)

Kerjasama antara Presiden dengan DPR juga harus melihat sistem kelembagaan yang dianut oleh UUD 1945 setelah perubahan yaitu pemisahan kekuasaan berdasarkan prinsip saling mengendalikan/mengawasi dan saling mengimbangi (checks and balances). Dalam sistem ini tiap-tiap lembaga negara (DPR, DPD, MPR, Presiden dan Wakil Presiden, Mahkamah Agung dan Mahkamah Konstitusi, dan BPK) memiliki fungsi-fungsi sendiri yang telah ditetapkan secara tegas oleh UUD, namun dengan checks and balances akan dapat dicegah penyalahgunaan kekuasaan oleh lembaga pemegang kekuasaan tertentu atau terjadi kebuntuan dalam hubungan antar lembaga.

Sistem ini tidak menghendaki antar lembaga saling menjatuhkan dan menghambat, namun antar lembaga harus saling bekerjasama melalui fungsinya masing-masing untuk mencapai tujuan negara sebagaimana termaktub dalam Pembukaan UUD 1945. Oleh karenanya menjadi sebuah keniscayaan dan keharusan bagi siapapun Presiden dan Wakil Presiden terpilih nanti untuk melakukan kerjasama dengan DPR dan juga dengan lembaga negara lainnya. Begitu juga sebaliknya, menjadi kewajiban DPR dan lembaga negara lainnya untuk mendukung segala kebijakan Presiden dan Wakil Presiden sepanjang kebijakan tersebut baik dan ditujukan untuk kepentingan rakyat.
Pemisahan kekuasaan berdasarkan prinsip checks and balances menghendaki DPR dalam melaksanakan fungsinya yaitu fungsi legislasi, fungsi anggaran dan fungsi pengawasan tetap proporsional. Setiap Anggota DPR harus bersikap kritis dan berani menolak Rancangan APBN yang diajukan Presiden apabila didalamnya secara nyata tidak ditujukan untuk kepentingan rakyat banyak dan hanya menguntungkan segelintir kelompok. Sebaliknya anggota DPR harus mendukung Rancangan APBN yang didalamnya berpihak kepada kepentingan rakyat (pro rakyat) meskipun partai politik dari anggota DPR tersebut tidak menjadi bagian dari pemerintahan/kabinet.

Jika UUD 1945 setelah perubahan telah menggariskan seperti itu, maka menjadi tidak tepat tindakan terutama pimpinan partai politik apabila kerjasama yang sematamata didasarkan pada kesepakatan bagi-bagi kursi dengan menomorduakan atau tidak menganggap penting penyusunan ide atau progam dalam menyelesaikan persoalan bangsa. Tidak tepat pula tindakan pimpinan partai politik yang karena mendapatkan jatah menteri di kabinet kemudian memerintahkan anggotanya yang duduk menjadi anggota DPR untuk tidak lagi kritis terhadap semua kebijakan Presiden dan Wakil Presiden meskipun secara nyata terdapat kebijakan yang tidak sesuai dengan Pancasila sebagai dasar dan ideologi negara, serta konstitusi negara. Sebaliknya juga tidak layak perilaku pimpinan Partai politik yang karena tidak mendapat jatah menteri di kabinet maka akan memerintahkan anggotanya di DPR untuk "menghambat dan menyerang" setiap kebijakan Presiden dan Wakil Presiden dengan sama sekali tidak memperdulikan pertimbangan bahwa kebijakan tersebut dibutuhkan oleh rakyat.

\section{Simpulan}

Supremasi konstitusi dianut oleh Indonesia sebagaimana termaktub dalam Pasal 1 ayat (2) UUD 1945 yaitu Kedaulatan berada di tangan rakyat dan dilaksanakan menurut Undang-Undang Dasar. Konsekuensi dianutnya supremasi konstitusi maka UUD 1945 di- 
letakkan sebagai hukum negara yang tertinggi di Indonesia. Hal demikian berarti menghendaki segala kehidupan kenegaraan termasuk pelaksanaan pemilihan Presiden dan Wakil Presiden, kerjasama Partai politik maupun hubungan antara Presiden dan Wakil Presiden dengan DPR dilakukan dengan membaca ketentuan dalam UUD 1945 sebagai konsensus bersama atau general agreement seluruh warga negara mengenai bangunan yang diidealkan berkenaan dengan negara.

Dalam kaitan dengan kerjasama Partai politik dalam pemilihan Presiden dan Wakil Presiden selama ini baru sebatas menciptakan kerjasama taktis yang bersifat sesaat antar Partai politik sehingga tidak melahirkan kerjasama jangka panjang yang dapat melahirkan penyederhanaan partai politik secara alamiah sebagaimana kehendak awal para perumus perubahan UUD 1945. Presiden dan Wakil Presiden terpilih dalam membangun kerjasama dengan DPR harus memahami bahwa UUD 1945 menempatkan Presiden dalam posisi yang kuat sehingga dalam masa jabatannya tidak dapat dijatuhkan oleh DPR selain karena alasan dan proses yang secara limitatif telah ditentukan dalam UUD 1945. Selain Posisi Presiden dalam hubungannya dengan DPR adalah sejajar dengan prinsip hubungan yang saling mengawasi dan mengimbangi.

Untuk itu kedepan kerjasama antar partai politik dalam mengusung calon Presiden dan calon Wakil Presiden di Pemilihan Presiden dan Wakil Presiden harus didorong menuju model kerjasama yang memperkuat sistem pemerintahan presidensial. Pengusulan pasangan calon Presiden dan calon Wakil Presiden oleh gabungan partai politik harus diarahkan untuk membentuk kerjasama permanen dari partai politik atau gabungan partai politik yang kemudian akan menyederhanakan sistem kepartaian sebagaimana dikehendaki oleh UUD 1945.

\section{Daftar Pustaka}

Asshiddiqie, J., Manan, B. dkk. 2006. Amandemen UUD 1945 dan Pemilihan Presiden Secara Langsung, Jakarta: Setjen \& Kepaniteraan MKRI.

Asshiddiqie, J. 2013. “Dinamika Partai Politik dan De- mokrasi". www.jimly.com/makalah/namafile/.../ Dinamika_Partai_Politik.d..., diakses 2 Juni 2014.

Budiardjo, M. 1989. Dasar-Dasar Ilmu Politik. Jakarta: Gramedia Pustaka Utama.

Caramani, D. 2008. Comparative Politic, New York: Oxford University Press.

Fatwa, A.M. 2009. Potret Konstitusi Pasca Amandemen UUD 1945. Jakarta: Kompas.

Hidayat, A. 2006. Kebebasan Berserikat Di Indonesia (Suatu Analisis Pengaruh Perubahan Sistem Politik Terhadap Penafsiran Hukum). Semarang: Badan Penerbit Universitas Diponegoro.

Ismanto, I., Perkasa, V. et al. 2004. Pemilihan presiden secara langsung 2004: dokumentasi, analisis, dan kritik. Jakarta: Galang Press. Kementerian Ristek, dan CSIS.

Isra, S. 2001. "Pemilihan Presiden Langsung". Kompas, 24 September 2001, http://www.saldiisra.web. id/index.php?option $=$ com_content $\&$ view $=$ ar ticle\&id =23: pemilihanpresidenlangsung\&cati $\mathrm{d}=1$ :artikelkompas\&ltemid $=2$, diakses 1 Juni 2014.

Komisi Pemilihan Umum (KPU). 2010. Modul I Pemilih Untuk Pemula. Jakarta: KPU

Lijphart, A. 2002. Parliamentary versus Presidential Government. New York: Oxford University Press.

Suny, I. 1983. Pergeseran Kekuasaan Eksekutif, Suatu Penyelidikan Dalam Hukum Tata Negara, Jakarta: Aksara Baru.

Sekretariat Jenderal MPR. 2012. Panduan Pemasyarakatan Undang-Undang Dasar Negara Republik Indonesia Tahun 1945 dan Ketetapan Majelis Permusyawaratan Rakyat Republik Indonesia. Jakarta: Sekjend MPR.

Sekretariat Jenderal dan Kepaniteraan Mahkamah Konstitusi. 2005. Laporan Penelitian "Mekanisme Impeachment dan Hukum Acara Mahkamah Konstitusi" Kerjasama Mahkamah Konstitusi Republik Indonesia dengan Konrad Adenauer Stiftung. Jakarta.

Sekretariat Jenderal dan Kepaniteraan Mahkamah Konstitusi. 2005. 2010. Naskah Komprehensif Perubahan Undang-Undang Dasar Negara Republik Indonesia Tahun 1945 Latar Belakang, Proses, dan Hasil Pembahasan, 1999-2002, Buku IV Kekuasaan Pemerintahan Negara,Jilid I, Jakarta: Sekjend MK.

Sekretariat Jenderal dan Kepaniteraan Mahkamah Konstitusi. 2005. 2010, Naskah Komprehensif Perubahan Undang-Undang Dasar Negara Repub- 
lik Indonesia Tahun 1945 Latar Belakang, Proses, dan Hasil Pembahasan, 1999-2002, Buku I Latar Belakang, Proses dan Hasil perubahan UUD 1945, Jakarta: Sekjend MK.

Supriyanto, D., dan Mellaz, A. 2011. Ambang Batas Perwakilan, Pengaruh Parliamentary Threshold Terhadap Penyederhanaan Sistem Kepartaian dan Proporsionalitas Hasil Pemilu. Jakarta: Perludem.

Santoso, T., dkk. 2006. Penegakan Hukum Pemilu, Praktik Pemilu 2004, Kajian Pemilu 2009-2014. Jakarta: Perludem.
The Indonesian Institute. 2010. Indonesia 2009, Jakarta: The Indonesian Institute.

The Indonesian Institute. 2010. "Update Indonesia, Tinjauan Bulanan Ekonomi, Hukum, Keamanan, Politik, dan Sosial". Volume: V, No. 7 - November.

Tempo. 2014. "Transaksi Dahulu Koalisi Kemudian". Majalah Edisi 26 Mei-1 Juni.

Yuda A.R., Hanta. 2010. Presidensialisme Setengah Hati, Dari Dilema Ke Kompromi, Jakarta: Gramedia Pustaka Utama 